\title{
Novel Translation for Sustainable Vertical Housing in Urban Environment
}

\author{
Anastasia M.D. Setyo Murni ${ }^{1}$, FX Teddy Badai Samodra ${ }^{1}$
}

\begin{abstract}
Urban housing has already led vertical development such as the improvement for slum settlement. In fact, this solution has not been considered optimal and even cause other problems. This study offers the concept of a vertical kampung by applying the translation of the identity of a traditional value. Sustainable design methods with field measurements, interviews and design simulations using Ecotect analysis-RADIANCE and ANSYS Fluent software as an integrated environmental consideration with the completion of social and economic sustainability were conducted. The results show that new methods using sustainable architectural principles should also be done. In addition, design of affordable dwelling from slums environment can also be transformed into new user empowerment and carrying capacity for the city.
\end{abstract}

Keywords - Integrated, Sustainable, Urban environment, Vertical housing

\section{INTRODUCTION}

Indonesia as a developing country runs a national development program to improve all aspects of community life. Jakarta as the Capital of the State of Indonesia has always been at the forefront of development, various technological developments are applied to create facilities that facilitate its inhabitants.

Along with the rapid development program in Jakarta many people who are still lagging behind or living in the poverty line. The Central Bureau of Statistics (BPS) (2015) says 384,300 Jakarta residents live below the poverty line, meaning that $3.93 \%$ of Jakarta's population is unable to meet their basic needs, both in food and nonfood sectors. The slum settlement problem is the one that must be addressed so as not to cause other problems such as crime and disease, which will hamper the growth rate of the city (Figure 1).

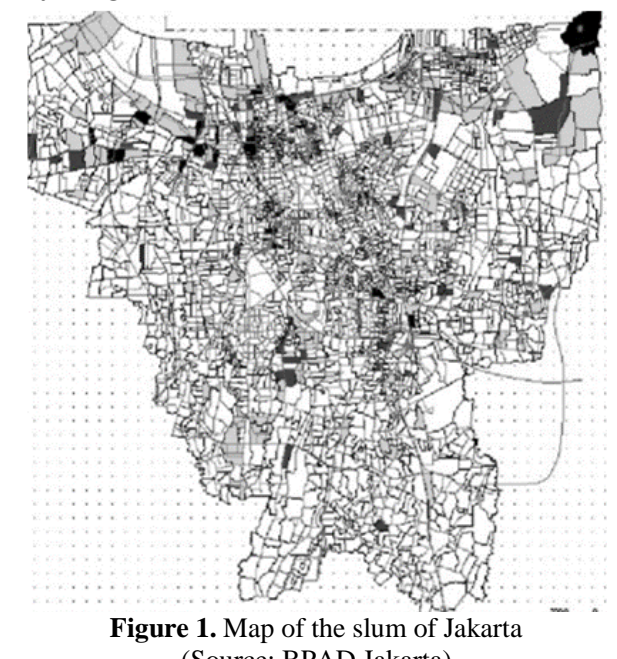

(Source: BPAD Jakarta)

\footnotetext{
${ }^{1}$ Anastasia M.D. Setyo Murni and FX Teddy Badai Samodra are from Department of Architecture, Faculty of Architecture, Design, and Planning, Institut Teknologi Sepuluh Nopember (ITS), Kampus ITS Sukolilo, Surabaya 60111, Indonesia. E-mail: delfieralauw@gmail.com; fxteddybs@arch.its.ac.id.
}

Architecture is one of the keys in development, which has a role to combine and align the physical and non-physical aspects of the city itself. Non-physical aspects such as social, economic, cultural, law and community are often forgotten by the Government, a city should not only have formed by sophisticated buildings or high buildings but from its own society [1]. Architecture must take a role in adjusting the development of the city to the needs of its people, mainly for fulfill the basic needs in the context of settlements and the development of the vertical housing.

\section{Issue and Design Context}

Establishment of vertical housing or dwelling is a solution given by DKI Jakarta Government to solve the problem of slum settlement, but in reality this solution does not work well. Construction of Rusunawa is often a problem, about 40\% Rusunawa not been used properly. Moreover, many inhibited Rusunawa have degraded in quality, damaged and leaked. The fact gives the impression that there has been a slum movement, from horizontal to vertical slum. Based on these events it can be concluded that in the future, the planning of Rusunawa or the other residence program must be based on the human needs. According to the theory of Maslow's hierarchy of needs when man has successfully fulfilled his basic needs, then man will have the motivation to meet other needs such as security, comfort, belonging and love. Home should not only be a place to stay but also to help people fulfil the higher needs. Maslow's needs hierarchy has a role as a reference in creating a decent shelter [2].

The criteria of decent and quality housing, which is a decent house that ensures security, provides easy access to employment and other service facilities and selfselected low cost environments [3]. The survey also revealed that almost all of its correspondents wanted a sustainable dwelling where sustainable means that people want to continue living with the same community in the same place for now and in the future "people / neighbors continuing to want to live in the same community, both now and in the future." This sustainable nature is concerned with the human need for compassion and appreciation and can be obtained when humans can live, work and do other things in the same place. In addition to sustainable social life, there are other important aspects of sustainability to the environment, in accordance with the three pillars that are key to sustainable development, namely social, economic, and environmental (Outcome of UN World Summit).

Various human activities in urban areas increase industrial activities, development, transportation and various household activities that produce carbon emissions and waste that pollute the environment. In the future, settlement planning should also be based on sustainable principles not only on the social economy but 
also on the environment. Meanwhile, according to Lawson [4], concept of integrated design for settlements should provide a central shared facility that belongs to the group appears to be one way to strengthen the community, and appears equally effective. Therefore, this research was conducted to design a good quality vertical housing with attention to social, environmental and economic aspects as a solution for the settlement of slum settlement in Johar Baru, Jakarta as research location (Figure 2).

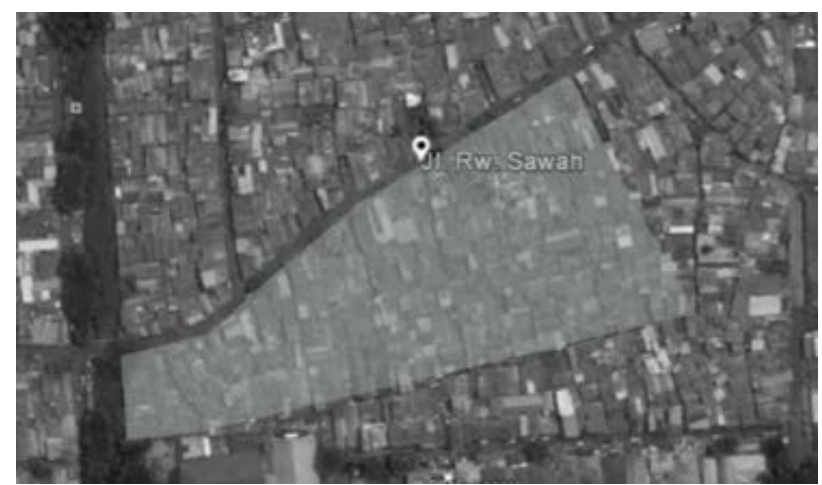

Figure 2. Slum area in Johar Baru (Source: google maps)

\section{METHOD}

The process of making this design used a method which commonly referred to as 'glass box'. This method is an objective and systematic way of thinking to examine things logically and free from irrational thoughts and considerations, such as sentiments and tastes. This method always tries to find facts and causes or factual reasons underlying the things that happen or vice versa. This way of thinking is also commonly referred to as reasoning. In this design, the method of 'glass box' is chosen because in accordance with the design objectives which is to create an integrated settlement built based on the needs of its inhabitants. The design concept is based on the systematic approach. Systematic design uses the sequences of analysis, synthesis, and evaluation, which can be translated into a series of stages that include programming, data collection, analysis, synthesis, development and communication (Figure 3). Analysis requires data and reduces the design requirements required for a complete performance specification. Synthesis involves finding solutions and developing a complete design. The evaluation stage assesses the accuracy of an alternative design to meets the performance requirements.

The design research method is integrating environmental consideration with the completion of social and economic sustainability. Field measurements, interviews and design simulations using Ecotect analysis-RADIANCE and ANSYS Fluent software are also used to support design process.

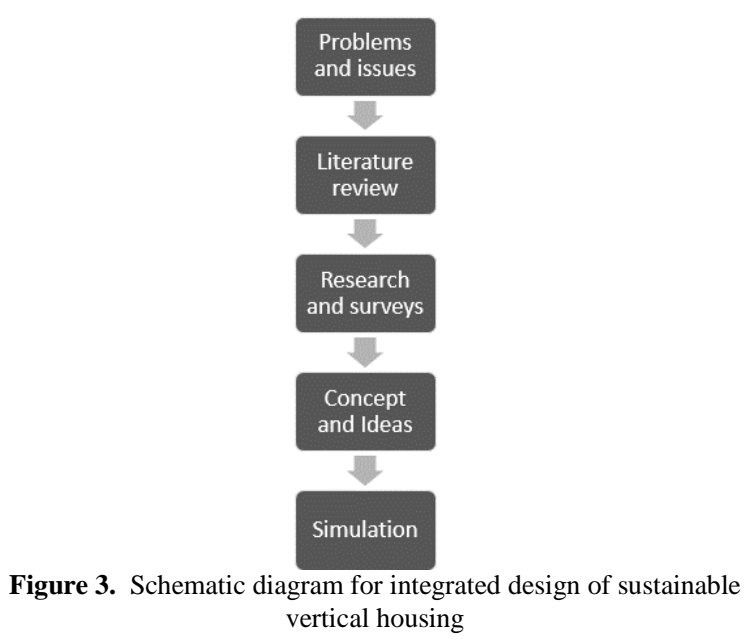

Research and Surveys

The research method for the projects surveys is combining the use of quantitative and qualitative analysis techniques sequentially or non-sequentially [5]. This study uses mixed methods because it allows researchers to harness the ability of quantitative and qualitative analysis techniques, so that they can get the phenomenon better, and the ability to find more and provide opportunities to create more meaning, thus improving the quality of data interpretation.

Population in this research is family resident of RW 02 Sub-district of Johar Baru. The sampling technique used in this research is the random sampling or the random sampling from existing population, which means every element of population have an equal opportunity for being the sample [6]. The recommended minimum number of sample for this comparative study is as many as 20 samples for each group [7].

The aim of this survey is to determine the comfort level of citizen in term of environment aspect. Based on the surveys result the citizen of Johar Baru Sub District feels slightly uncomfortable on temperature (indicated by scale 1) of their neighborhood (Table 1).

TABLE 1.

ENVIRONMENT COMFORT

\begin{tabular}{llllllll}
\hline \hline \multirow{1}{*}{ Aspect } & \multicolumn{5}{c}{ Scale (low to high) } \\
\cline { 2 - 7 } & -3 & -2 & -1 & 0 & 1 & 2 & 3 \\
\hline Temperature & & & & & & & \\
Humidity & & & & & & & \\
Thermal comfort & & & & & & & \\
Air flow & & & & & & & \\
Daylight & & & & & & \\
\hline \hline
\end{tabular}

\section{RESULTS AND DISCUSSION}

The integration of the sustainable concept and the fulfillment of human needs can be an answer to the current Rusunawa's problem. The novel idea of vertical housing in urban environment can be a concept for the future Rusunawa development. In general, the design criteria for creating novel idea could be shown in Table 2 for all aspects and contexts and the implementation are illustrated. 
TABLE 2.

DESIGN CRITERIA

\begin{tabular}{|c|c|c|c|}
\hline $\begin{array}{l}\text { Aspect/ } \\
\text { Context }\end{array}$ & social & environment & $\begin{array}{l}\text { Sege } \\
\text { economy }\end{array}$ \\
\hline site & $\begin{array}{l}\text { Creating the } \\
\text { circulation and } \\
\text { accessibility spaces } \\
\text { that suits to the } \\
\text { needs of its users }\end{array}$ & $\begin{array}{l}\text { Maximizing } \\
\text { green open } \\
\text { space; } \\
\text { Generating } \\
\text { climatic } \\
\text { potency }\end{array}$ & $\begin{array}{l}\text { Increasing } \\
\text { the value of } \\
\text { strategic } \\
\text { locations area }\end{array}$ \\
\hline $\begin{array}{l}\bar{E} \bar{E} \\
\text { building }\end{array}$ & $\begin{array}{l}\text { Creating an } \\
\text { affordable home; } \\
\text { Accommodating } \\
\text { social and cultural } \\
\text { activities; } \\
\text { Providing designs } \\
\text { that provide } \\
\text { comfort and } \\
\text { security }\end{array}$ & $\begin{array}{l}\text { Applying an } \\
\text { energy-efficient } \\
\text { utility system }\end{array}$ & $\begin{array}{l}\text { Selecting } \\
\text { materials and } \\
\text { effective- } \\
\text { efficient } \\
\text { structure } \\
\text { types }\end{array}$ \\
\hline
\end{tabular}

\section{A. Environment Criteria}

Environmental sustainability means development that retains natural resources to last longer. Low density areas initially designated as catchment areas (water catchment areas) turned into housing land. Therefore, it is necessary to apply a new strategy to maximize the function of land. Although it is a low-cost settlement, it does not mean that the environmental issues are ruled out. The environment is a key factor to create a comfortable and safe environment for the inhabitants [8]. These are the criteria for sustainable design in environmental aspect.

\section{Maximize greenery}

It is important to maximize the amount of greenery on site; the green site prevent heat gains to keep areas cool. The greenery must be providing wherever possible like on the playground, sport court, parking lot, pathways and any other outdoor areas. For the need of hardscape surface areas, it uses permeable paving that provide water catcher to allow infiltration during rain (Figure 4).
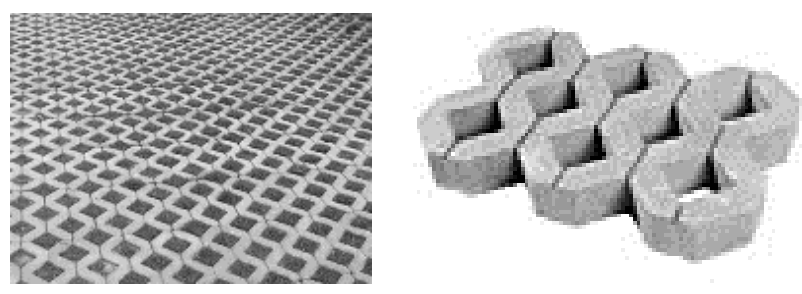

Figure 4. Permeable grid paving (source: Westview concrete)

\section{Building orientation}

In accordance with Kenneth Yeang's theory, the entire building mass has an $\mathrm{x}$ :y ratio equal to $1: 3$ with diagonal orientation from the North-South perpendicular direction. If integrated with the best orientation based on Jakarta City climate data, then the building has the orientation as follows. The longest span towards the southeast (Figure 5).

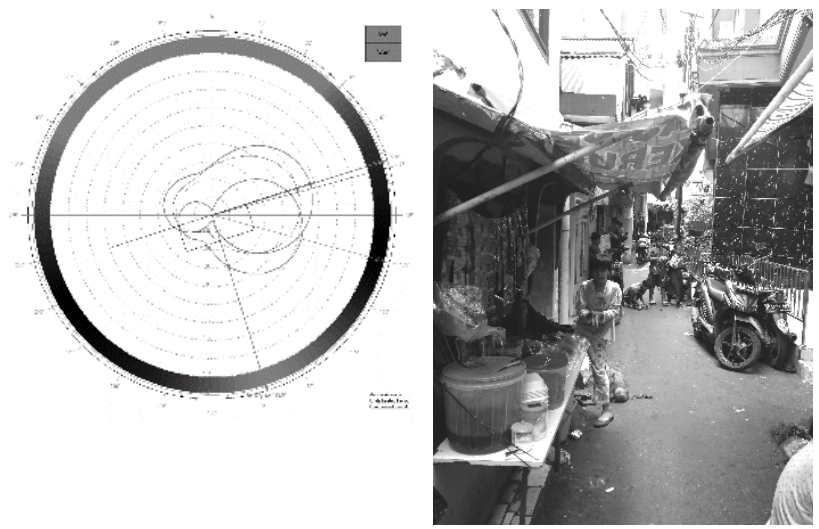

Figure 5. Jakarta best orientation (Source: Ecotect analysis)

\section{Building Massing}

A customizing building layout can be used as the wind catcher to create passive cooling, the wind direction on the site context is one of the considered factor (Figure 6). Massing and orientation are also important factors.
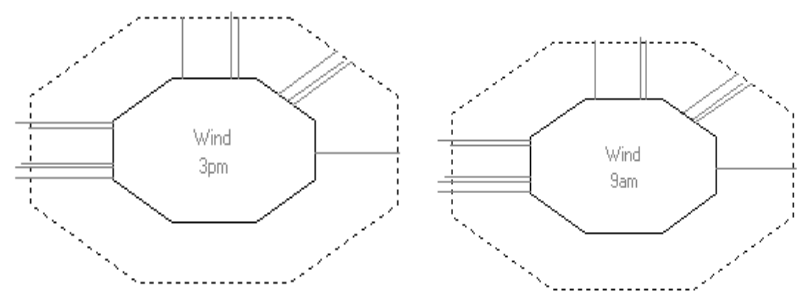

Figure 6. Jakarta wind direction

\section{Passive lightning strategy}

Since lighting is one of the things that use the most of electricity in this household scale, it is an important thing to know how many openings area such as window or ventilation are needed, a right window design also supports passive lighting. Based on many published strategies for daylighting a building, daylight glazing is most effective above $2,100 \mathrm{~mm}$, vision glazing is typically applied between $7,50 \mathrm{~mm}$ and 2,100 $\mathrm{mm}$. Adding light shelves is also needed to bring daylight further into spaces (Figure 7). For bringing daylight into more depth space, the installation of mirror ducts and sun pipes are needed (Figure 8). The application of daylighting in Indonesia tends to be consistent in collecting light sources. The illustration in Figure 9 below is the plan of solar pipe or mirror duct installation.

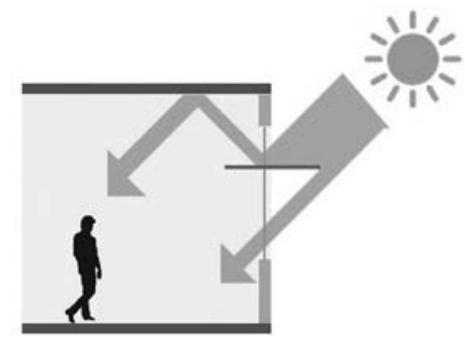

Figure 7. Light shelf illustration 


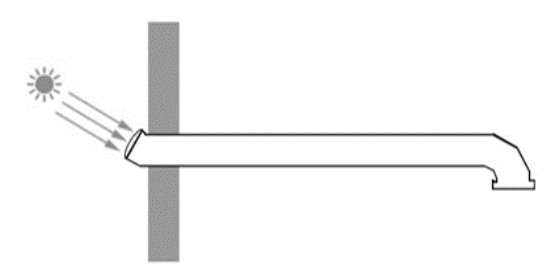

Figure 8. Light pipe illustration

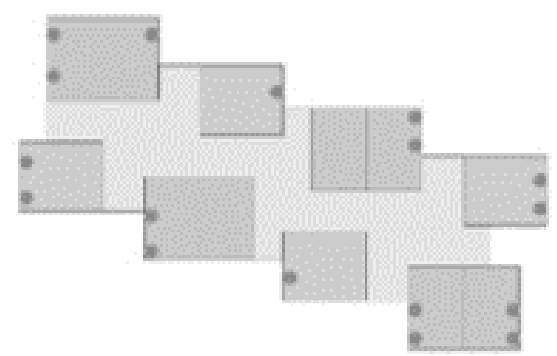

Figure 9. Light pipe installation plan

\section{Water harvesting}

One of the way to utilize rain water is to create a rain water harvesting system. It collects or stores rainwater from the roof of the building or from the ground surface during rain. Rainwater catchment can also infiltrate through permeable pavement. This rain water harvesting system can be the solution to help providing the large amount of water requirement in a vertical housing. Figure 10 below is the rain water harvesting scheme that can be applied in Johar Baru Vertical Housing.

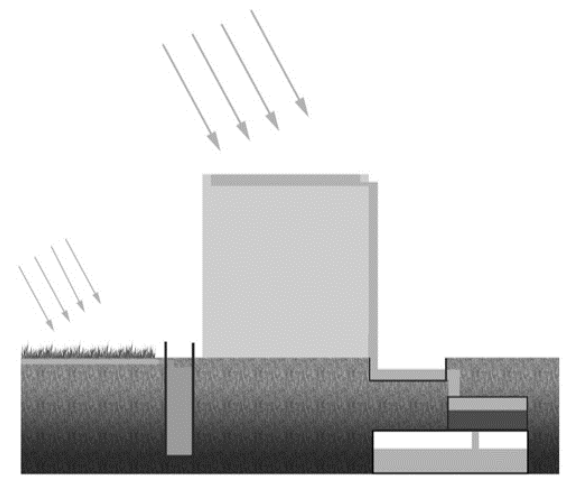

Figure 10. Rain water harvesting System

\section{B. Social Criteria}

\section{The use of circulation area}

'Sustainable on social criteria' means that the development is able to maintain the character of the local social circumstances. However, it would be better if the development is actually improving the existing social quality. Everyone is involved in the development so create a social stability to form a conducive culture. One of the social criteria is 'to accommodate the social activities of its inhabitants'. Users of the vertical dwellings are residents who have long lived together in dense settlements there is a strong bonds of social interaction exist between them (Figure 11), this culture must be accommodated in their new environment. The residents of apartment buildings are more likely to be socially connected with their neighbors perhaps because the distances distance between neighbors in a vertical housing building is lower [1]. This criterion can be the idea for design the circulation in vertical living area, when the corridor was not only used as a circulation area but also a living space that many social activities took place (Figure 12).

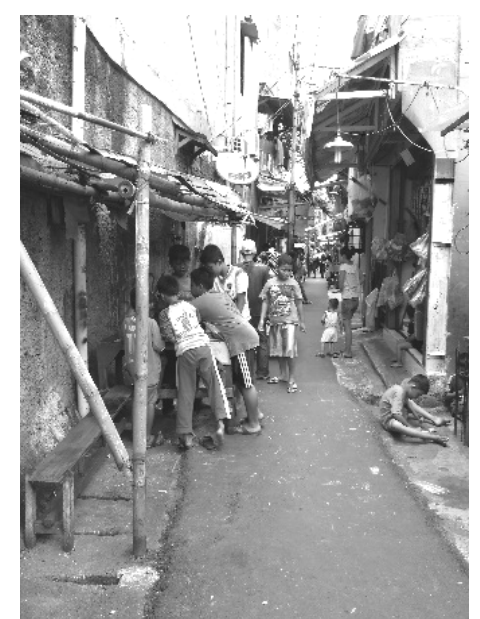

Figure 11. Site setting where the circulation area is also the playground and shop area

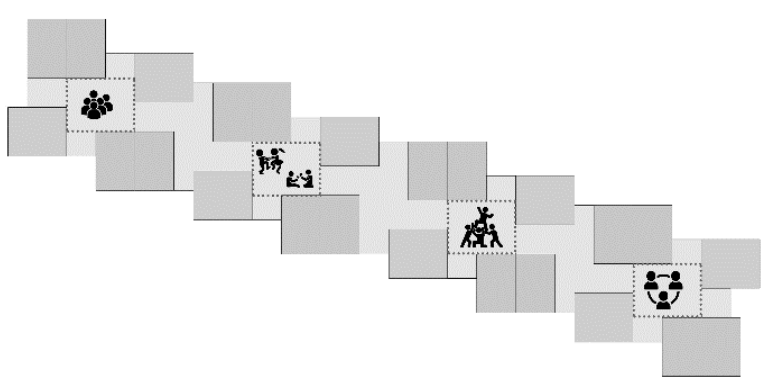

Figure 12. Illustration for living area design

\section{To adding more communal space}

The new housing building must contain an area to hold the communal activities, mainly the existing activities such $P K K$, arisan, pengajian and posyandu. The criteria of well design communal space in housing area are approachable, not disturbing a circulation flow and has 'welcome' impression [9]. Based on these criteria, the communal areas should be separated from residential areas but still available on each floor.

\section{Economy Criteria One stop living}

The one stop living idea is a multifunction building which in this context the vertical housing building should not only provide home but also a working area. The adding of working area in the building will improve the building's land use value. The work area can be a workshop or shop house which accommodate the residents' business so that they do not lose their livelihood. For the future development, the working area is utilized for the public.

\section{Rapid construction}

As the need of a decent quality housing is an urgent thing. The importance of improving productivity in the building and construction of vertical housing was most recently highlighted by the government. The use of 
prefabricated structures has become very popular nowadays (Figure 13). The main advantages of prefabricated structures are assembly of finished elements on site, self-load bearing and quick execution.

The idea of using structural steel frame construction deserve a further research, as there was rarely midrise housing that use steel frame as the main structure materials. This kind of structure such a reliable choice for the rapid construction strategy. Steel parts are prefabricated into specific design and can be assembled in the site. This speeds up construction time significantly. However, the idea of steel construction also has disadvantage especially for applied in vertical housing structure. The steel material is more flammable than concrete material, the solution to resolve this problem is by covering the steel with a composite material. Besides using steel frame as the structural construction the material things to consider is the 'walling system' material. The infill walling system infill wall refers to panel that is built in between the floors of the primary structural frame of a building and provides support for the cladding system and generally installed on site. This light panel makes the building construction process faster than the block infill wall system.

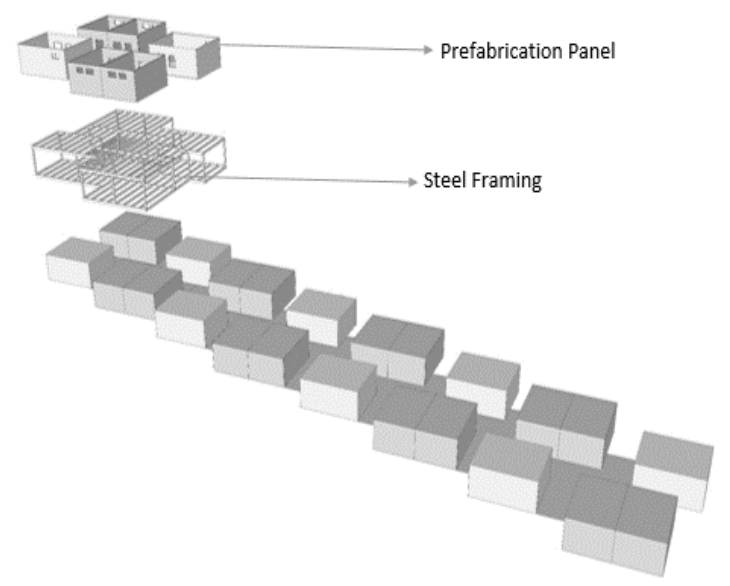

Figure 13. Illustration of building structure

\section{Floor efficiency ratio}

Building Floor Efficiency is the most important factor in the concept of building design in terms of cost and economic factors. The ratio is between assignable and leasable areas are in a floor the building. The efficiency ratio can be measured by NGR (Net Gross Ratio) formula. The efficiency standard for vertical housing buildings is $0.67-0.80$ for the main function of the entire building is the living area and the rest is used for service, circulation, etc.

\section{Integrated Design}

All of the sustainable design concept for vertical housing must be integrated. The integration output is also affect a vertical housing formal aspect, from the overall form of the building the type of access, building massing and the type of units. To reach the performance requirements goal this research also use Ecotect analysisRADIANCE and ANSYS Fluent software.

\section{Building form}

To maximize the green area, create a huge communal and get the best building orientation therefore the basic building form is block and the blocks arrange as the site form so make an efficiency space (Figure 14). Then, the overall building form gets simulated in ANSYS Fluent software and the result is in Figure 15 below. The wind can pass through each side of the building and the narrower alley can increase the wind velocity.

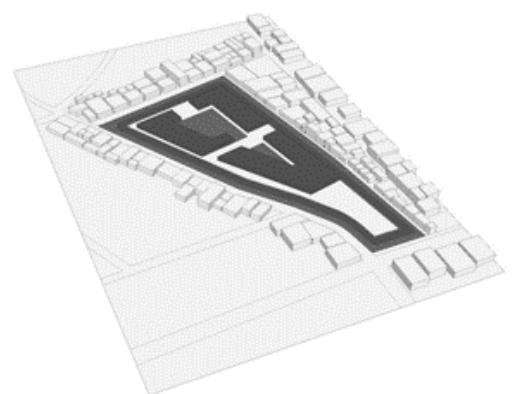

Figure 14. Illustration of building massing

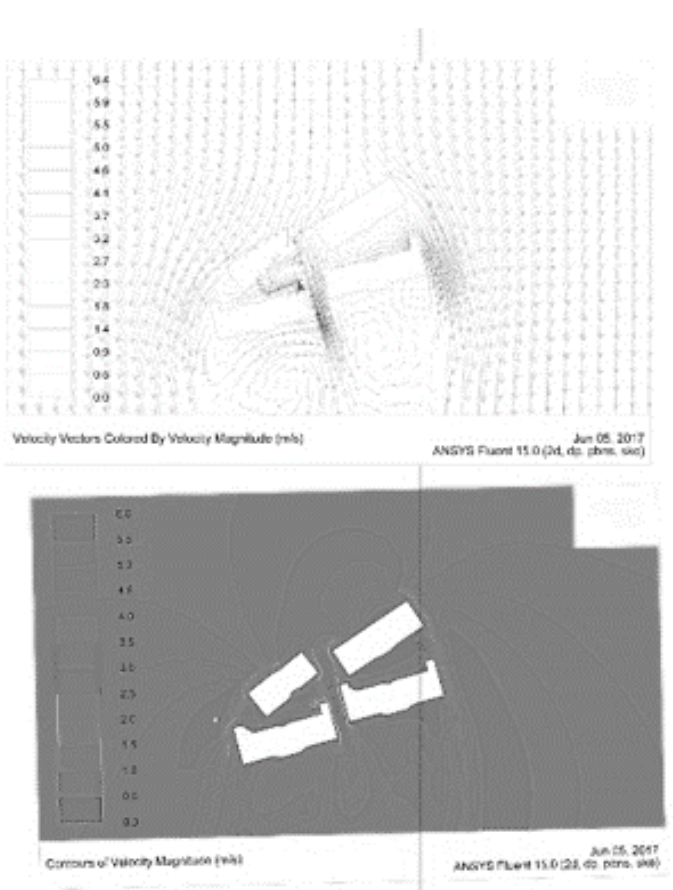

Figure 15. Overall building wind simulation (Source: ANSYS Fluent Software)

\section{Type of Layouts}

A unique layout arrangement should be based on environment, economy and social aspect. Therefore, this design not use the general singular corridor type anymore (Figure 16). The living units arranged by the wind direction and the needs of the occupants. However, in term of economy aspect, the layout design must follow the efficiency standard. The priority of the layout design is to provide more spacious social area.

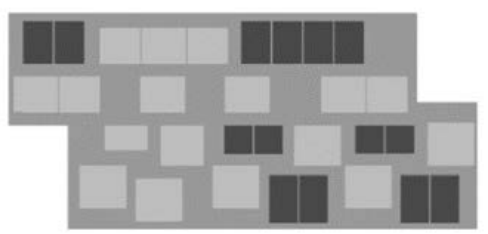

Figure 16. Illustration of layout arrangement 
The layout design is simulated by ANSYS Fluent software to know the ability of building for create the passive energy such the passive cooling. The wind is flowing and passing through all the alley and on some alley of the velocity of the wind is increased (Figure 17). This is good for the passive cooling in internal areas.

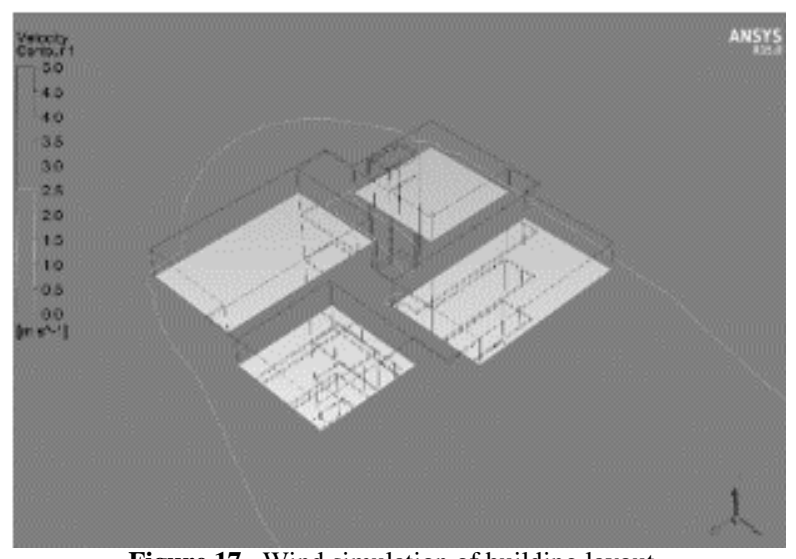

Figure 17. Wind simulation of building layout (Source: ANSYS Fluent Software)

\section{Type of Units}

The different types of unit layout designed to have enough space to meet the needs of the intended number of occupants. The type of the unit are the family unit, studio unit and the shop house unit (Figure 18-20).

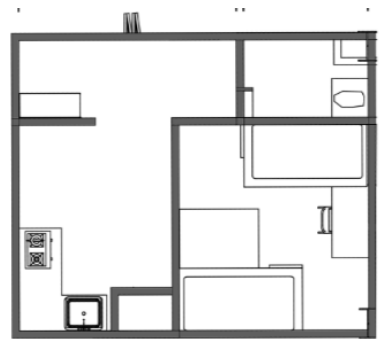

Figure 18. Design of shop house unit

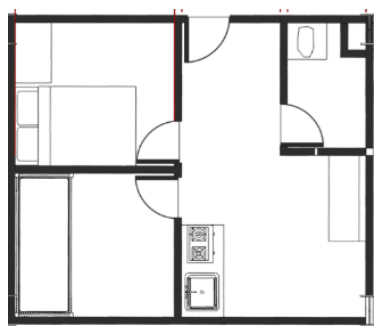

Figure 19. Design of family unit

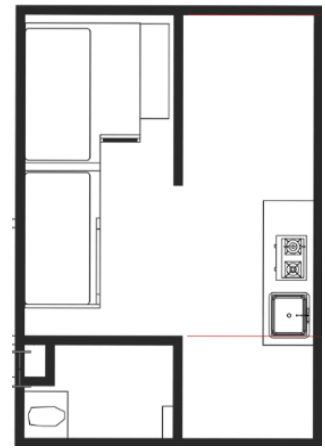

Figure 20. Design of studio unit
In term of environment aspect, the application of passive energy system on unit scale applied on the windows and ventilation design (Figure 21). The opening areas sufficient to provide the wind passing through into the room. Daylight simulation results requiring light pipes installation (Figure 22).

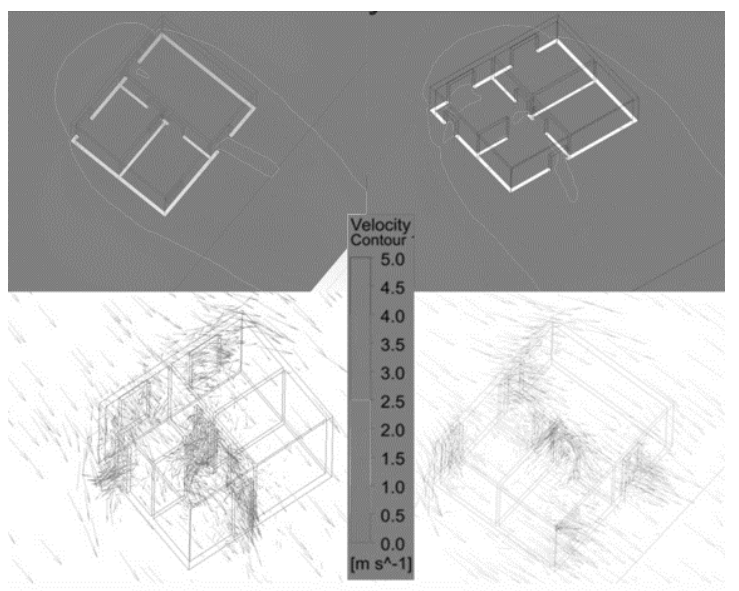

Figure 21. Wind simulation of the unit design (Source: ANSYS Fluent Software)
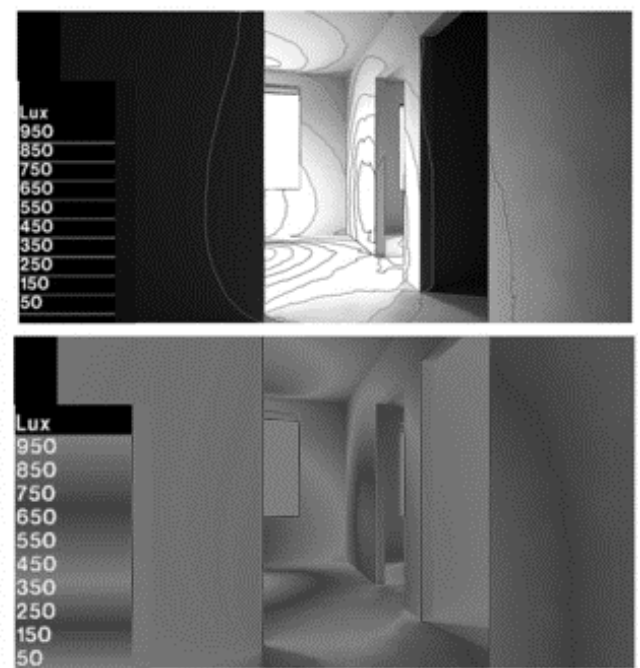

Figure 22. Daylight simulation (Source: ANSYS Fluent Software)

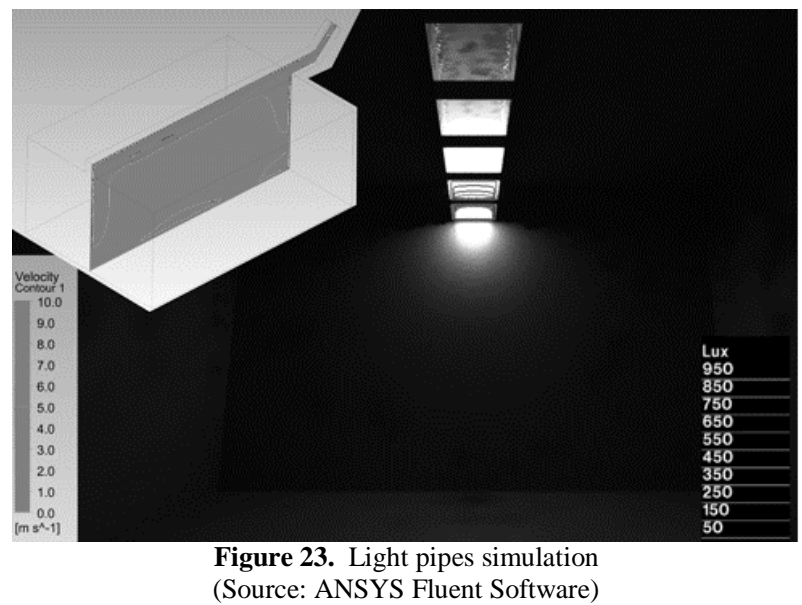

Based on the design implementation above, a critical point is designing light pipe for non-opened room. Thus, Figure 23 offers light pipe design combined with air duct as passive method to reduce additional cost. It is also relevant to economy aspect and has no conflict to social 
The $3^{\text {rd }}$ International Seminar on Science and Technology August $3^{\text {rd }}$ 2017, Postgraduate Program Institut Teknologi Sepuluh Nopember, Surabaya, Indonesia

needs. In other hand, the most important point as novel translation from horizontal settlement to vertical housing is providing comfort site and building communal spaces (Figure 24).

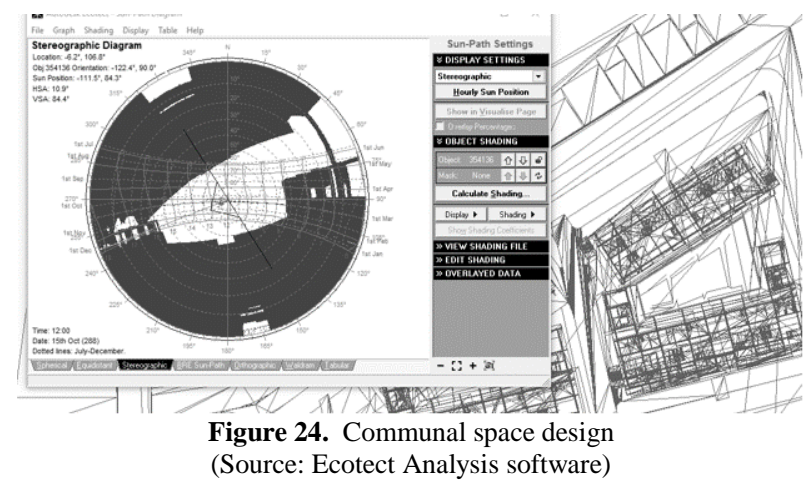

\section{CONCLUSION}

As Zavei and Jusan [2] analysis related to Maslow's hierarchy of needs potency in forming data to create an affordable housing, novel design method using sustainable architectural principles has been designed. The integrated of the social, economy and environment aspect have to meet the occupants needs, Therefore, it is such an important thing to doing a research or survey before designing a vertical housing especially for the cultural based community such as Johar Baru. Interviews and design simulations using Ecotect analysisRADIANCE and ANSYS Fluent software is also needed as an integrated environmental consideration. In addition, by this design idea, a comfortable housing from slums land and transformed new user empowering and city capacity could also be translated.

\section{ACKNOWLEDGMENT}

This research is publication of Final Project Report, Department of Architecture-ITS Surabaya supported by Penelitian Doktor Baru No. 881/PKS/ITS/2017, Dana Non PNBP ITS 2017. The authors gratefully acknowledge this financial and technical supports.

\section{REFERENCES}

[1] E. Glaeser and B. Sacerdote, "The Social Consequences of Housing,” Cambridge, MA, Dec. 2000.

[2] S. J. A. P. Zavei and M. M. Jusan, "Exploring Housing Attributes Selection based on Maslow's Hierarchy of Needs," Procedia Soc. Behav. Sci., vol. 42, pp. 311-319, Jan. 2012.

[3] S. M. S. Baqutayan, A. S. B. Ariffin, and F. Raji, "Describing the Need for Affordable Livable Sustainable Housing Based on Maslow's Theory of Need,” Mediterr. J. Soc. Sci., vol. 6, no. 3 S2, pp. 353-357, May 2015.

[4] B. Lawson, The Language of Space. Oxford: Architectural Press, 2001.

[5] J. M. Morse and L. Niehaus, Mixed method design: principles and procedures. Left Coast Press, 2009.

[6] S. Arikunto, Prosedur Penelitian: Suatu Pendekatan Praktik. Jakarta: Rineka Cipta, 2002.

[7] J. R. Fraenkel and N. E. Wallen, How to Design and Evaluate Research in Education. New York: McGraw-Hill, 1993.

[8] H. A. Karim, "Low Cost Housing Environment: Compromising Quality of Life?,” Procedia - Soc. Behav. Sci., vol. 35, pp. 44-53, Jan. 2012.

[9] R. Darmiwati, "Studi Ruang Bersama Dalam Rumah Susun Bagi Penghuni Berpenghasilan Rendah,” Dimensi. - J. Archit. Built Environ., vol. 28, no. 2, pp. 114-122, 2000. 